\title{
Cocaine Differentially Inhibits Neuronal Differentiation and Proliferation In Vitro
}

\author{
Ditza Zachor, ${ }^{\star}$ Joseph K. Cherkes, ${ }^{\star}$ Charles T. Fay, ${ }^{*}$ and lan Ocrant * \\ *Department of Pediatrics, Brown University and Rhode Island Hospital, and ${ }^{\ddagger}$ Toxicology Laboratory, Rhode Island Hospital, \\ Providence, Rhode Island 02903
}

\begin{abstract}
The outcome of in utero cocaine exposure is unclear. To determine if cocaine affects neuronal growth and differentiation, we used PC-12 cells, which have a mitogenic response to IGF-I and differentiate into neurons on exposure to nerve growth factor. Differentiation was quantified as neurite extension after a 72-h exposure to $20 \mathrm{ng} / \mathrm{ml}$ nerve growth factor (dosage at $50 \%$ maximal effectiveness ) and cocaine doses ranging from 0.01 to $10 \mu \mathrm{g} / \mathrm{ml}$. The results were $49 \pm 2,40 \pm 3,29 \pm 2,23 \pm 2$, and $12 \pm 2 \%$ differentiation with respective cocaine concentrations of $0,0.01,0.1,1$, and $10 \mu \mathrm{g} / \mathrm{ml}(P<0.0001)$. Cocaine stability studies showed insignificant spontaneous hydrolysis under the conditions of this study. Cocaine did not affect cell viability or number, but had a relatively modest, statistically significant $(P$ $<0.0001$ ) inhibitory effect on IGF-I-stimulated thymidine incorporation. The dose-response curves for differentiation vs mitogenic response differed significantly $(P=0.021)$. Therefore, cocaine inhibition of these processes is probably mediated by different mechanisms, and not caused by generalized toxicity. To our knowledge, this is the first demonstration of cocaine effects on neuronal multiplication and differentiation in vitro. The results suggest in utero exposure may directly impair brain development. (J. Clin. Invest. 1994. 93:1179-1185.) Key words: cocaine - PC-12 cells • neuron - cell differentiation • growth factors
\end{abstract}

\section{Introduction}

Prenatal cocaine abuse complicates $\sim 10-20 \%$ of urban pregnancies and about $6 \%$ of rural pregnancies $(1,2)$. The outcome of this exposure is yet unclear; individuals may be cognitively or behaviorally impaired from the potentially permanent damage to the developing brain (3).

Clinical studies are not consistent in their reports of outcome (1-6). A major difficulty is the presence of confounding variables, such as the effect of other illicit drugs and socioenvironmental factors $(1,2,7)$. Also, adverse effects on neurologic and behavioral functions may be delayed for years and may not be easily measured by standardized tests $(1,3,8-10)$.

Animal studies suggest that cocaine disturbs central nervous system development (11-15), but the mechanism of effect may be related to indirect vascular side effects of cocaine,

Address correspondence to Ian Ocrant, M.D., Pediatric Endocrinology, Valley Children's Hospital, 3151 North Millbrook Avenue, Fresno, CA 93703.

Received for publication 1 March 1993 and in revised form 15 November 1993.

J. Clin. Invest.

(C) The American Society for Clinical Investigation, Inc.

0021-9738/94/03/1179/07 \$2.00

Volume 93, March 1994, 1179-1185 rather than direct effects on cell growth and differentiation $(16,17)$.

The emphasis of this study was to determine whether cocaine by itself directly affects neuronal growth and development. We hypothesized that cocaine directly impairs neuronal differentiation and/or growth.

As a model of in vitro neuronal differentiation, we used PC- 12 cells, a clonal cell line derived from a transplantable rat adrenal pheochromocytoma induced by $\mathrm{x}$-ray irradiation (1820 ). These cells grow in culture as undifferentiated neuroblast cells that are exquisitely sensitive to the mitogenic effects of IGF-I. When exposed to picomolar concentrations of nerve growth factor (NGF), ${ }^{1}$ the cells cease multiplying and differentiate into mature, electrochemically competent neurons (21). This differentiation is characterized by extension of long, branching, axodentritic, varicose processes $(18,20)$, electrical excitability, increased neurotransmitter synthesis, and formation of cell-cell synaptic contacts (22). Because of their ability to survive in both undifferentiated and differentiated states, their morphogenic response to NGF, and mitogenic response to IGF-I (23), we used them as a model to study direct effects of cocaine on the processes of NGF-stimulated neuronal differentiation and IGF-I-stimulated cell replication.

We also studied the stability of cocaine, under the conditions of this study, to ensure that appropriate amounts of cocaine were present throughout the exposure period. As best we can determine, such cocaine stability data are not published elsewhere.

To our knowledge, this is the first study of cocaine effects on these processes at the cellular level. This well-defined in vitro cellular model will be important for future studies to determine the biochemical mechanisms of these effects.

\section{Methods}

\section{Materials}

PC-12 cells were purchased from the American Type Culture Collection (Rockville, MD), and only early passage cells were used in this study. Vitrogen, a collagen cell attachment matrix, was purchased from Collagen Corp. (Pato Alto, CA). Fetal calf serum, horse serum, transferrin, BSA, sodium selenite, triiodothyronine $\left(\mathrm{T}_{3}\right)$, progesterone, and cocaine hydrochloride were purchased from Sigma Immunochemicals (St. Louis, MO). Cocaine hydrochloride was also purchased from Alltech Associates (Houston, TX). Culture medium, trypsin-EDTA, and L-glutamine solutions were purchased from Gibco Laboratories (Grand Island, NY). Recombinant human $N$-Met-IGF-I was purchased from Bachem, Inc. (Torrance, CA). Recombinant human insulin (Humulin-R) was purchased from Eli Lilly and Co. (Indianapolis, IN). 7S NGF was purchased from Collaborative Research, Inc. (Bedford, MA). Lidocaine was purchased from Astra Scientific Interna-

1. Abbreviations used in this paper: $\mathrm{ED}_{\mathbf{5}}$, dosage at $50 \%$ maximal effectiveness; $\mathrm{IC}_{50}$, dosage at $50 \%$ maximal inhibition; NGF, nerve growth factor; SCM, serum-containing medium; SFM, serum-free medium. 
tional, Inc. (Pleasanton, CA). $\left[{ }^{3} \mathrm{H}\right]$ thymidine was purchased from New England Nuclear (Boston, MA).

\section{Procedures}

Cell culture. PC-12 rat pheochromocytoma cells were initially cultured in RPMI 1640 medium, supplemented with $5 \%$ fetal calf serum, $10 \%$ horse serum, and $0.292 \mathrm{mg} / \mathrm{ml} \mathrm{L}$-glutamine, designated as serum-containing medium ( $\mathrm{SCM}$ ), under $7.5 \% \mathrm{CO}_{2}$. Cells were cultured in plastic tissue culture flasks (Corning Glass Incorporated, Wexford, PA). coated with Vitrogen according to the manufacturer's directions. Only low passage cells (10-15 maximum passages) were used. Chemically defined serum-free medium (SFM), consisting of RPMI 1640, 0.1\% BSA, insulin $5 \mu \mathrm{g} / \mathrm{ml}$, transferrin $100 \mu \mathrm{g} / \mathrm{ml}$, sodium selenite $100 \mu \mathrm{g} /$ $\mathrm{ml}$, progesterone $20 \mathrm{nM}$, and $\mathrm{T}_{3} 10 \mu \mathrm{M}$, was used in the differentiation studies.

$N G F$-stimulated PC-12 cell differentiation studies. Effects on NGFstimulated PC-12 differentiation are most sensitively detectable at the middle of the log-linear dose-response curve. Therefore, we determined the dosage at $50 \%$ maximal effectiveness $\left(\mathrm{ED}_{50}\right)$, the dose yielding $50 \%$ maximal differentiation for NGF-stimulated PC-12 differentiation, and used this concentration for studying cocaine effects on this process.

To determine the $\mathrm{ED}_{50}$ for NGF, dose-response curves for NGF-induced differentiation were performed. 100,000 cells were plated on six-well polystyrene tissue culture plates (Becton Dickinson Labware, Lincoln Park, NJ). Cells were grown for $4 \mathrm{~d}$ in SCM, then NGF was added to all groups in concentrations of $0,1,5,10,50,100$, and 1,000 $\mathrm{ng} / \mathrm{ml}$. Dose-response curves in SCM and SFM were determined in two separate experiments performed in triplicate.

Neuronal differentiation was estimated after $72 \mathrm{~h}$ exposure to NGF by morphological parameters, specifically by the striking appearance of axondendritic processes $>40 \mu \mathrm{m}$ long (or about four cell diameters) detected by phase contrast microscopy $(20,21,23)$. Differentiation was quantitated as the percentage of cells bearing axondendritic processes greater than four cell diameters in length $(20,21) .100$ cells were examined per field, in three separate fields per well, in triplicate wells per treatment group, in three separate experiments on different days using different cultures.

Cocaine effect on NGF-stimulated PC-12 differentiation was estimated after $72 \mathrm{~h}$ exposure to $20 \mathrm{ng} / \mathrm{ml}$ NGF in SFM, and $30 \mathrm{ng} / \mathrm{ml}$ NGF in SCM, the respective $\mathrm{ED}_{50}$ concentrations under these conditions, and cocaine in concentrations of $0,0.01,0.1,1$, and $10 \mu \mathrm{g} / \mathrm{ml}$. These cocaine concentrations range from innocuous to extremely toxic, based on human toxicology data (24-26). In the SFM experiments, media, and additives were changed daily.

After determining the percentage of differentiated cells, viability and cell number were estimated by trypan blue exclusion and cell counting using a hemocytometer.

IGF-I-stimulated $\left[{ }^{3} \mathrm{H}\right]$ thymidine incorporation studies. The $\mathrm{ED}_{50}$ for IGF-I-stimulated PC-12 $\left[{ }^{3} \mathrm{H}\right]$ thymidine incorporation was determined for the same reasons as for NGF-stimulated differentiation. The dose response-curve was generated using cells at a confluency consistent with the exponential phase of growth. PC-12 cells were cultured at 300,000 cells/well (in six-well plates) for $4 \mathrm{~d}$ in SCM. Cells were washed twice with PBS, then synchronized and made quiescent by serum starvation for $24 \mathrm{~h}$ in RPMI 1640 supplemented with $0.15 \%$ fetal calf serum and $0.05 \%$ horse serum. On day 5 , medium was aspirated and cells were exposed for $24 \mathrm{~h}$ to IGF-I at $0,0.1,0.2,0.4,1,5,10$, 50 , and $100 \mathrm{ng} / \mathrm{ml}$, using a medium consisting of RPMI 1640 with $1 \%$ BSA.

To determine the effect of cocaine on IGF-I-stimulated DNA synthesis, cells were cultured and treated as described above. On day 5, cocaine was added in concentrations of $(0.01-10 \mu \mathrm{g} / \mathrm{ml})$ to $0.3 \mathrm{ng} / \mathrm{ml}$ IGF-I (the $\mathrm{ED}_{50}$ ) in RPMI 1640 with $1 \%$ BSA for $24 \mathrm{~h}$.

After treatment with IGF-I with or without cocaine, DNA synthesis was estimated by $\left[{ }^{3} \mathrm{H}\right.$ ] thymidine incorporation. $2 \mu \mathrm{Ci}\left[{ }^{3} \mathrm{H}\right.$ ] thymidine were added to each treatment well for $4 \mathrm{~h}$. Then media were aspirated to separate tubes. Cells were washed six times with ice-cold $0.9 \% \mathrm{NaCl}$.
Dislodged and floating cells in the aspirated medium and wash solutions were collected by centrifugation at $600 \mathrm{~g}$ for $5 \mathrm{~min}$. Samples were lysed by adding $0.33 \mathrm{~N} \mathrm{NaOH}, 3.5 \mathrm{ml}$ to iced wells, and $3.5 \mathrm{ml}$ to iced tubes (containing the centrifuged cells), and incubated for $15 \mathrm{~min}$ at $37^{\circ} \mathrm{C}$. The lysates were combined and incubated for $15 \mathrm{~min}$ at $55^{\circ} \mathrm{C}$, cooled for $10 \mathrm{~min}$, and $2.5 \mathrm{ml}$ of $40 \%$ TCA in $1.2 \mathrm{~N} \mathrm{HCl}$ were added to tubes and incubated on ice for $10 \mathrm{~min}$. Using a suction manifold, precipitate was collected on glass filters. Filters were washed six times in $10 \%$ TCA to remove unincorporated counts, dried overnight, placed in scintillation cocktail, and then counted.

\section{Cocaine stability studies}

Instrumentation. Quantitation of cocaine in culture media was performed on a glass chromatograph (model 8410; Perkin-Elmer Cetus Instruments, Norwalk, CT) equipped with a nitrogen-phosphorus detector and a data processing module (model 746; Waters Chromatography Division, Milford, MA). The chromatographic column was a $15 \mathrm{~m}$ $\times 0.53-\mathrm{mm}$ internal diameter capillary column ( $\mathrm{J} \& \mathrm{~W}$ Scientific, Folsom, CA) with a $1-\mu \mathrm{m}$ film thickness. The program had no initial hold time, but the final hold time was $5 \mathrm{~min}$. Oven temperature was ramped at a rate of $4^{\circ} \mathrm{C}$, to a final temperature of $250^{\circ} \mathrm{C}$. Detector gases were hydrogen, air, and nitrogen make up set at $9.0,22.0$, and $55.0 \mathrm{ml} / \mathrm{min}$, respectively. Helium carrier flow was $10 \mathrm{ml} / \mathrm{min}$. The initial oven temperature was $200^{\circ} \mathrm{C}$, and the injector and detector temperatures were 250 and $300^{\circ} \mathrm{C}$, respectively. The instrument was set to high sensitivity and energy to the rubidium bead was set at level $2(\sim 20 \mathrm{pA})$.

Extraction and quantitation of cocaine. From a substock standard of cocaine $(0.01 \mathrm{mg} / \mathrm{ml})$, working standards of cocaine were prepared in $8 \%$ BSA with concentrations of $0.5,1.0,2.0$, and $5.0 \mu \mathrm{g} / \mathrm{ml}$. A standard curve was prepared and run alongside each sample batch. The assay proved sensitive for the detection of cocaine down to $0.01 \mu \mathrm{g} / \mathrm{ml}$. To assay, $1 \mathrm{ml}$ of standard or sample was placed in a $16 \times 150-\mathrm{mm}$ disposable borosilicate tube to which $1 \mathrm{ml}$ of saturated borate buffer, pH 10.5, was added. $100 \mu$ l of working internal standard was added to each tube (lidocaine, $0.01 \mathrm{mg} / \mathrm{ml}$ ) and vortexed. Cocaine was extracted from standards and samples by adding $10 \mathrm{ml}$ of $n$-butyl chloride and agitating on a shaking apparatus for $10 \mathrm{~min}$. Because of the unadulterated nature of the samples (no drugs other than cocaine present), it was determined that a back extraction would be superfluous. After $10 \mathrm{~min}$, the standards and samples were centrifuged, and $9 \mathrm{ml}$ of the organic phase was transferred to $15 \mathrm{ml}$ conical tubes to which $200 \mu \mathrm{l}$ of a $1 \%$ methanolic $\mathrm{HCl}$ solution was added to diminish the potential for thermal destruction of the cocaine by forming a hydrochloride salt. The standards and samples were gently evaporated in a concentrating apparatus under a gentle stream of nitrogen at $50^{\circ} \mathrm{C}$ to dryness. The standards and samples were reconstituted with $100 \mu$ l of ethyl acetate and vortexed for $15 \mathrm{~s}$ to ensure thorough mixing. One $2-\mu \mathrm{l}$ aliquot of the reconstituted sample was then introduced into the gas chromatograph, and the developing chromatogram was monitored. The elution order was lidocaine ( $5.05 \mathrm{~min}$ ) and cocaine $(9.35 \mathrm{~min}$ ), respectively. Linearity of the standard curve was excellent $(r=0.9998)$ and reproducible. Concentrations of the unknown samples were determined from the standard curve by least squares regression analysis (27-31).

Cocaine stability. The cocaine level was assessed in both SCM and SFM after 24 and $72 \mathrm{~h}$ using the same conditions described in the differentiation studies. Cocaine concentration was also measured in SFM, after daily changes of medium containing fresh NGF and cocaine, at the end of the third change ( $72 \mathrm{~h}$ of cumulative exposure).

\section{Data analysis}

Data from thymidine incorporation experiments and neurite extension experiments were analyzed separately by one-way ANOVA. When ANOVA suggested significant differences between groups $(P<0.05)$, individual group means were compared by the Student-NewmanKeuls multiple comparisons test. These tests were performed using Instat 2.0 (GraphPad Software, San Diego, CA).

The shape of the dose-response curves for thymidine incorporation 
and neurite extension were compared after the data from each experiment were normalized so that the mean value at a cocaine dose of 0 $\mu \mathrm{g} / \mathrm{ml}$ equaled $100 \%$, and the mean value at a cocaine dose of $10 \mu \mathrm{g} / \mathrm{ml}$ equaled $0 \%$. Dose-response curves were plotted using the appropriate algorithm of Grafit (Erithicus Software, London). The shape of the dose-response curves indicated that near maximal inhibition was attained at a cocaine dose of $10 \mu \mathrm{g} / \mathrm{ml}$, indicating this normalization procedure is reasonable. These data were then logarithmically transformed to obviate heterogeneous variance. Dose-response data were then analyzed by two-way ANOVA using SigmaStat version 1.01 (Jandel Scientific, San Rafael, CA).

Cocaine degradation kinetics were analyzed using the kinetics algorithm of GraFit. Curves were obtained with extremely tight fit; i.e., with low $\chi^{2}(P<0.05)$.

\section{Results}

Dose-response for NGF-stimulated PC-12 neuronal differentiation. The NGF $\mathrm{ED}_{50}$ concentration was determined from doseresponse curves for NGF-induced PC-12 differentiation in SFM (Fig. 1) and SCM (not shown). These $\mathrm{ED}_{50}$ are $20 \mathrm{ng} / \mathrm{ml}$ for SFM and $30 \mathrm{ng} / \mathrm{ml}$ for SCM. Changes in the quantity and quality of PC-12 differentiation could be easily detected at these concentrations. The average percentage of differentiated cells at the $20 \mathrm{ng} / \mathrm{ml}$ was $49 \%$ in SFM.

Cocaine effect on NGF-stimulated PC-12 differentiation. In SFM, cocaine had a significant dose-related inhibitory effect on NGF-stimulated PC-12 neuronal differentiation (Fig. 2 and Table I). Differences were prominent especially in the high cocaine dosage (Fig. 3 ). The dosage at $50 \%$ maximal inhibition $\left(\mathrm{IC}_{50}\right)$ for cocaine inhibition of NGF-stimulated PC-12 neurite extension was $0.11 \mu \mathrm{g} / \mathrm{ml}$. Maximal inhibition achieved was $77 \%$ of the $\mathrm{ED}_{50} \mathrm{NGF}$ response.

To determine that the cocaine inhibitory effect on NGFstimulated differentiation was not caused by general cell toxicity, viability was measured by trypan blue exclusion and cell counting on all NGF- and cocaine-treated groups. No significant differences in the percentage of viable cells or total viable cells were noted ( Table I).

In SCM, cocaine had no effect on NGF-stimulated PC-12 differentiation (not shown). This is probably caused by breakdown of cocaine by serum pseudocholinesterase (see cocaine stability studies, below).

Dose-response for IGF-I-stimulated PC-12 $\left[{ }^{3} \mathrm{H}\right]$ thymidine incorporation. We determined the IGF-I ED 50 from the dose response curve for IGF-I-stimulated PC-12 cells to be $0.3 \mathrm{ng} /$ ml (Fig. 4).

Cocaine effect on IGF-I-stimulated PC-12 $\left[{ }^{3} \mathrm{H}\right]$ thymidine incorporation. Graded doses of cocaine were added to PC-12 cells stimulated by $0.3 \mathrm{ng} / \mathrm{ml}$ IGF-I. Cocaine had relatively

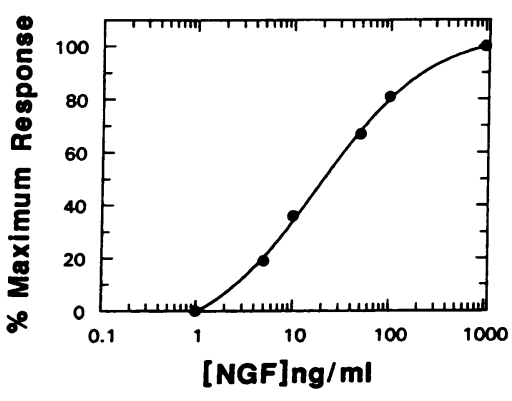

Figure 1. Dose-response curve of NGF-induced PC-12 cell neuronal differentiation in SFM. The $\mathrm{ED}_{\mathrm{so}}$ concentration derived from the curve was $20 \mathrm{ng} / \mathrm{ml}$.

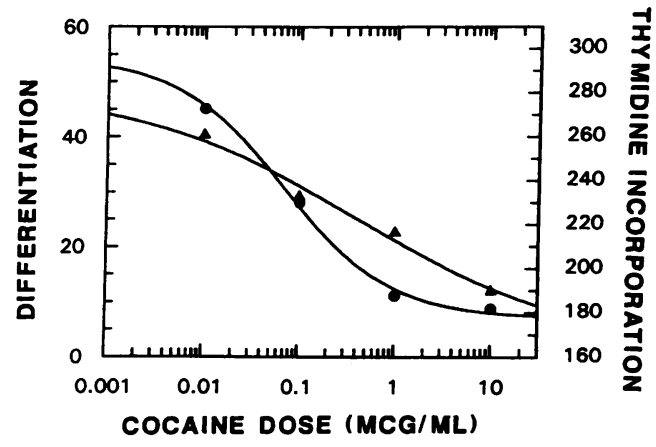

Figure 2. Cocaine dose-effect on PC-12 cell NGF-stimulated neurite extension (triangles) and on IGF-I-stimulated $\left[{ }^{3} \mathrm{H}\right]$ thymidine incorporation (circles) in SFM. PC-12 cells were treated with NGF at the $E_{50}$ concentration of $20 \mathrm{ng} / \mathrm{ml}$ and graded doses of cocaine. Left vertical axis shows the percentage of differentiated cells. The maximal percentage differentiation obtained from the NGF treated (no cocaine) control group was $49 \%$. Data presented as means of three experiments performed in triplicate. Right vertical axis shows thymidine incorporation expressed as percentage, normalized so that basal incorporation without exposure to IGF-I $=100 \%$ and expressed as the mean of 24-25 wells in five experiments. Because of baseline noise at cocaine doses of 1 and $10 \mu \mathrm{g} / \mathrm{ml}$, data for thymidine incorporation were smoothed to facilitate curve fitting using the binomial smoothing algorithm of GraFit; hence, the minor differences between the plotted data points and the data in Table II.

modest (maximum $56 \%$ inhibition of the $\mathrm{ED}_{50}$ response), but statistically significant $(P>0.0001)$, inhibitory, dose-related effects on $\left[{ }^{3} \mathrm{H}\right]$ thymidine incorporation (Table II).

The dose-response curve (Fig. 2) reached minimum at 1 $\mu \mathrm{g} / \mathrm{ml}$ compared with $10 \mu \mathrm{g} / \mathrm{ml}$ for neurite extension. At this concentration, the cells were clearly still capable of a robust

Table I. Cocaine Effects on NGF-stimulated PC-12 Differentiation and Viability

\begin{tabular}{lcccc}
\hline Group & $\begin{array}{c}\text { Cocaine } \\
\text { dose }\end{array}$ & $\begin{array}{c}\text { Percent of } \\
\text { differentiated } \\
\text { cells* }\end{array}$ & $\begin{array}{c}\text { Cell } \\
\text { number } \\
\times 10^{4} / \text { well }\end{array}$ & $\begin{array}{c}\text { Percent of } \\
\text { viable } \\
\text { cells } \pm \text { SEM }^{\natural}\end{array}$ \\
\hline & $\mu g / m l$ & & & \\
A & 0 & $49 \pm 2$ & $38 \pm 9$ & $89 \pm 2$ \\
B & 0.01 & $40 \pm 3$ & $41 \pm 9$ & $91 \pm 0.5$ \\
C & 0.1 & $29 \pm 2$ & $33 \pm 4$ & $93 \pm 2$ \\
D & 1.0 & $23 \pm 2$ & $35 \pm 2$ & $88 \pm 3$ \\
E & 10.0 & $12 \pm 2$ & $36 \pm 2$ & $86 \pm 2$ \\
\hline
\end{tabular}

* Comparison of the amount of differentiation with respect to cocaine concentration. Results were significant at $P<0.0001$ by ANOVA. Post hoc group comparisons were also significant by the StudentNewman-Keuls test $(P<0.001-0.05)$ for all possible comparisons. Note that the percent of differentiation without NGF and without cocaine was $2 \pm 0.4$.

¥ Cell number was measured by hemocytometry, counting $\geq 200$ cells from each of three wells per treatment group and expressed as mean \pm SEM.

$\$$ Viability was measured as mean \pm SEM of three wells per treatment condition, counting 100 cells in each of three separate fields per well. Differences between groups for viability and number were not significant by ANOVA ( $P=0.2$ for viable cells, $P>0.8$ for total cells). 

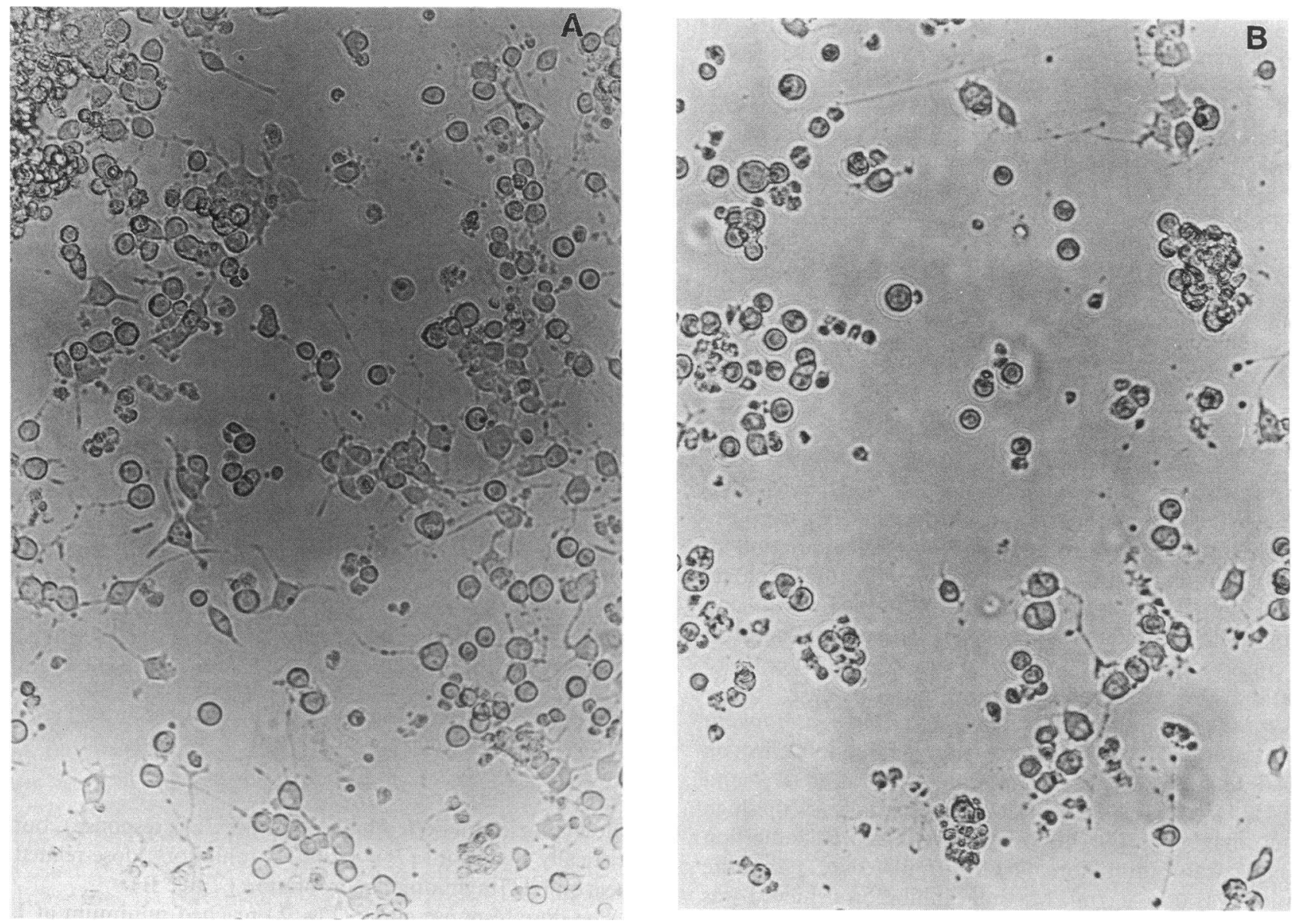

Figure 3. $(A)$ NGF-treated PC-12 neuronal differentiation after 72-h exposure to NGF at the $\mathrm{ED}_{50}$ concentration of $20 \mathrm{ng} / \mathrm{ml}$. Prominent neurite outgrowth is evident. ( $B)$ PC-12 cells exposed to both NGF $(20 \mathrm{ng} / \mathrm{ml})$ and high cocaine concentration $(10 \mu \mathrm{g} / \mathrm{ml})$ for $72 \mathrm{~h}$ in SFM. Note the significant reduction of neuronal differentiation.

mitogenic response ( $190 \%$ increase in thymidine incorporation compared with PC-12 cells that were not stimulated by IGF-I) at cocaine dosages that inhibited NGF-stimulated neurite extension by $77 \%$ of the $\mathrm{ED}_{50}$ response. The $\mathrm{IC}_{50}$ dose of cocaine for inhibition of thymidine incorporation was $0.07 \mu \mathrm{g} / \mathrm{ml}$.

In addition to differences in the shape of the dose-response curves and differences in the $\mathrm{IC}_{50}$ for cocaine effects on neurite extension and thymidine incorporation, comparison of transformed data showed that the differences in group means for neurite extension vs thymidine incorporation were greater than would be expected by chance after allowing for the effects of differences in the cocaine dose $(P=0.021)$ by two-way ANOVA. These data indicate that although cocaine affects both

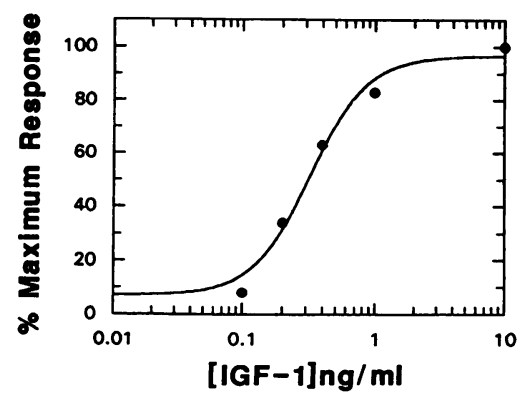

Figure 4. Dose-response curve for IGF-I-stimulated $\mathrm{PC}-12\left[{ }^{3} \mathrm{H}\right]-$ thymidine incorporation. The $\mathrm{ED}_{50}$ concentration for

IGF-I-stimulated PC-12 $\left[{ }^{3} \mathrm{H}\right]$ thymidine incorporation derived from the curve was $0.3 \mathrm{ng} / \mathrm{ml}$. neurite extension and DNA synthesis, it affects these processes differently.

Cocaine stability studies. To determine the stability of cocaine in SCM and SFM used in these experiments, we measured cocaine levels over time in both conditions (Fig. 5). Results showed cocaine degradation during the first $24 \mathrm{~h}$ in SCM, consistent with first-order kinetics, probably caused by enzymatic breakdown by pseudocholinesterase present in horse and calf serum $(400 \mathrm{U} / \mathrm{ml}$, measured in plain horse and calf serum by our toxicology laboratory). In SFM, slow spontaneous zeroorder kinetic degradation was observed suggesting spontaneous hydrolysis over time. However, daily changes of cocaine, medium, and additives resulted in a reasonably steady cocaine level over the entire experimental period.

\section{Discussion}

We have shown in this study that cocaine had direct dose-related inhibitory effects on NGF-stimulated PC-12 cell differentiation and on IGF-I-stimulated DNA synthesis. The dose-response curves were different for each of these inhibitory effects possibly indicating different mechanisms of inhibition. Cell viability and cell number were unaffected, and the cells' ability to respond to IGF-I was not ablated. Our study supports the concept that cocaine may have direct effects on neuronal replica- 
Table II. Cocaine Effects on $\left[{ }^{3} H\right]$ Thymidine Incorporation by IGF-I-stimulated Undifferentiated PC-12 Cells

\begin{tabular}{lccc}
\hline Group & IGF-I* & $\begin{array}{c}\text { Cocaine } \\
\text { dose }\end{array}$ & $\begin{array}{c}\text { Incorporation normalized } \\
\text { to group } F=100 \%^{*}\end{array}$ \\
\hline A & + & 0 & $306 \pm 23$ \\
B & + & 0.01 & $269 \pm 25$ \\
C & + & 0.1 & $247 \pm 21$ \\
D & + & 1.0 & $157 \pm 19$ \\
E & + & 10.0 & $190 \pm 21$ \\
F & - & 0 & 100 \\
\hline
\end{tabular}

${ }^{*}$ IGF-I ED ${ }_{s 0}$ concentration of $0.3 \mathrm{ng} / \mathrm{ml} ;{ }^{*} \pm \mathrm{SEM}$. Cocaine effect of $\left[{ }^{3} \mathrm{H}\right]$ thymidine incorporation of PC-12 stimulated by IGF-I at ED so $_{50}$ $(0.3 \mathrm{ng} / \mathrm{ml})$. Data were normalized to group $\mathrm{F}$ (an independent negative control, not treated with IGF-I or cocaine, and therefore not included in the ANOVA) by dividing the group mean dpm by the mean negative control dpm and multiplying by $100 . n=24-25$ wells per condition. Differences in group means were significant $(P<$ $0.0001)$. Post hoc multiple comparisons by the Student-NewmanKeuls procedure were significant $(P<0.001-0.05)$ only for groups $A$ and $\mathrm{D}, \mathrm{B}$ and $\mathrm{D}, \mathrm{C}$ and $\mathrm{D}, \mathrm{A}$ and $\mathrm{E}$, and $\mathrm{B}$ and $\mathrm{E}$.

tion and development during the prenatal period that may affect developmental outcome.

NGF-stimulated PC-12 cell neurite extension is a widely used model of neuronal differentiation. However, this cell line does not necessarily resemble cells in the intact brain. All cell models have this limitation. However, biochemical mechanisms thus uncovered can be examined in more complicated systems, now that changes can be identified and studied at the cellular level.

Neuronal differentiation was significantly reduced upon exposure to cocaine levels commonly found in the blood of known drug abusers $(25,26)$. However, previous cocaine pharmacokinetic studies done on rats (32) show that the placenta tends to concentrate cocaine as a result of low pseudocholinesterase activity, and does not present an effective barrier to cocaine during the fetal period $(32,33)$. Cocaine levels in fetal rat brain are two to three times that detected in maternal blood, implying that the fetal brain is probably subject to even higher doses than are seen in the blood.

Clinical studies indicate an increased incidence of prematurity, intrauterine growth retardation, and microcephaly in

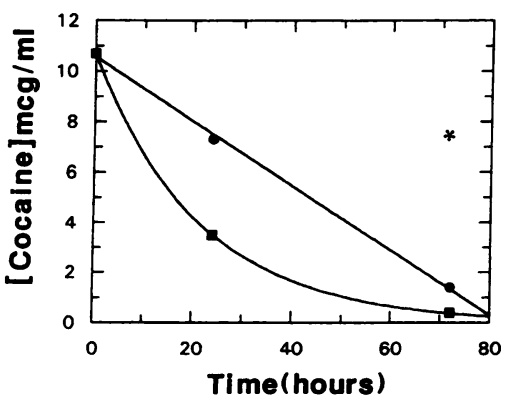

Figure 5. Cocaine stability over time in SFM and SCM. In SCM, the curve obtained showed a first-order decay characteristics, suggesting enzymatic breakdown. In SFM the curve obtained had a zero-order decay, implying a process of spontaneous hydrolysis. SEM values

were less than the width of the circle or triangle, and therefore are not shown in this figure. Square, cocaine in SCM condition; circle, cocaine in SFM condition. *Cocaine level in SFM after three daily changes of cocaine, NGF, and medium were in the same range as those obtained after $24 \mathrm{~h}$ in SFM. newborn infants exposed to cocaine during pregnancy (1-6). Several minor, short-lasting neurologic abnormalities were also described (34-36). Recently, there has been more clinical evidence that cocaine may have teratogenic effects during the process of brain development (37). However, clinical studies of neonates exposed to cocaine are controversial, mainly because of the confounding social and pharmacological variables that are difficult to control. Thus, neurobehavioral and cognitive outcomes of prenatal cocaine exposure are unclear. Furthermore, standard cognitive tests may not adequately assess the various developmental fields that may be affected from this exposure $(1,2,7)$, and abnormalities may take years to become evident.

Animal studies examining prenatal cocaine effects on brain development and function have been done. Adverse effects on myelination were reported by Wiggins et al. (38). Dramatic disturbances of neocortical cytoarchitecture after chronic fetal cocaine exposure were described by Gressens et al. (39). Several studies report lasting metabolic alterations, disturbed development and function of dopaminergic pathways, selective effects on noradrenergic neurotransmitter receptor and opiate receptor development, synaptic activity, and alteration in the serotonin system affecting serotonergic neuron formation. Altered neuronal pathways mediating motor, limbic, and neuroendocrine functions were also described (12-15, 40-45). Behavioral studies indicate specific long-term deficits of learning, behavior, and locomotor activity regulated by complex central neural pathways of rat offspring exposed to chronic in utero administration of cocaine, implying that specific brain sites are vulnerable to deleterious cocaine influences (12-15, 46-48).

Our findings of significant inhibition of PC-12 neuronal differentiation upon exposure to moderate to high cocaine levels suggest that cocaine may have direct effects on brain development, in addition to vascular side effects $(16,17)$ that could contribute to the adverse neurodevelopmental outcomes. An alteration in neuronal differentiation could alter subsequent processes of synaptogenesis during the critical period of cell differentiation and rapid axonal and dendritic expansion. Disrupted differentiation could also affect neuronal migration resulting in malformation or nonformation of specific neuronal pathways. The mechanism of action and critical time period for these effects and possible reversibility of the findings are yet to be explored.

Cocaine had a modest inhibitory effect on cell replication measured as DNA synthesis, and the magnitude of this effect was less than the effect on neurite extension. Cocaine was not toxic to differentiated cells per se, as estimated by trypan blue exclusion and cell counting. Thus, these cells are unlikely to be experiencing generalized toxicity from cocaine exposure, corroborating the cell count and viability data from Table I.

The modest inhibition of DNA synthesis we found is consistent with many animal studies that describe no significant effect on litter size, birth weight, and other growth indices, at cocaine exposures that clearly altered brain development, metabolism, and behavior (12-14, 38, 46-48).

Some studies do, however, report effects on cell replication. Interference with DNA synthesis in all brain regions after exposure to cocaine was described by Anderson-Brown et al. (49), a study that eliminated vascular side effects of cocaine as an uncontrolled variable. Our study does not contradict these findings, as Anderson-Brown et al. looked at thymidine incorpora- 
tion in postnatal brain tissue, and inhibition of incorporation may have reflected effects on glial cell replication, which is more active in the postnatal ages studied. Our model looked at incorporation in neuroblasts and is more likely to reflect processes occurring at a much earlier period in embryonic development, when neuroblasts are still rapidly replicating. Also, it is difficult to compare exposure dosages for in vitro exposures to tissue levels in vivo because the placenta preferentially transports cocaine to the fetus and fetal brain tissue concentrates cocaine.

On the other hand, cocaine-treated rat embryo cultures showed dose-dependent growth inhibition in vitro but not in vivo (50). Hypoxic ischemic insult secondary to systemic vascular side effects of cocaine could have contributed to these findings and have been reported in humans $(1,17)$. Future animal studies must carefully control for vascular side effects, as in the Anderson-Brown study, to generate useful data on direct actions of cocaine in neural tissues.

Cocaine instability was observed under certain conditions in our study. We negated this instability using SCM, because the presence of pseudocholinesterase activity in horse and calf serum appeared to cause enzymatic hydrolysis of cocaine to its inactive metabolites (references 51 and 52 and Fig. 5). Slower spontaneous degradation of cocaine in SFM was also documented and obviated by daily changes of media and additives.

PC-12 cells have achieved preeminence as a cellular model of neuronal differentiation and NGF action, and many neurobiologists feel this model may have broad biological and clinical applicability. To our knowledge, our paper is the first to establish a cellular model of cocaine effects on NGF-induced differentiation, demonstrating direct inhibitory effect of cocaine on this process. These results support the concept that in utero cocaine exposure may directly impair brain development. Therefore, cocaine-exposed fetuses may be at risk for subsequent adverse outcomes.

\section{Acknowledgments}

The authors would like to thank Dr. Judith T. Parmelee for her invaluable assistance with the statistical analyses.

\section{References} 407.

1. Volpe, J. J. 1992. Effects of cocaine on the fetus. N. Engl. J. Med. 327:399-

2. Frank, D. A., B. S. Zuckerman, H. Amaro, K. Aboagye, H. Bauchner, H. Cabral, L. Fried, R. Gingson, H. Kayne, S. M. Levenson, et al. 1988. Cocaine use during pregnancy: prevalence and correlates. Pediatrics. 82:888-895.

3. Singer, L. T., R. Garber, and R. Kliegman. 1991. Neurobehavioral sequelae of fetal cocaine exposure. J. Pediatr. 119:667-671.

4. Chasnoff, I., D. Griffith, S. McGregor, K. Dirkies, and K. Burns. 1989. Temporal patterns of cocaine use in pregnancy. J. Am. Med. Assoc. 261:17411741.

5. Chasnoff, I., W. J. Burns, S. H. Schnoll, and K. Burns. 1985. Cocaine use in pregnancy. N. Engl. J. Med. 313:666-669.

6. Kennard, M. J. 1990. Cocaine use during pregnancy: fetal and neonatal effects. J. Perinat. Neonat. Nurs. 3:53-63.

7. Lutiger, B., K. Graham, R. Einarson and G. Koren. 1991. Relationship between gestational cocaine use and pregnancy outcome: a meta-analysis. Teratology 44:405-414.

8. Rodning, C., L. Beckwith, and J. Howard. 1989. Characteristics of attachment organization and play organization in prenatally drug exposed toddlers. Dev. Psychopathol 1:277-289.

9. Chasnoff, I. J., D. R. Freier, and J. Murray. 1992. Cocaine/polydrug use in pregnancy: two year follow up. Pediatrics. 89:284-289.

10. Rodning, C., L. Beckwith, and J. Howard. 1989. Prenatal exposure to drugs: behavioral distortion reflecting CNS impairment? Neurotoxicology. 10:629-634.

11. Dow-Edwards, D. L. 1991. Cocaine effects on fetal development: a comparison of clinical and animal research findings. Neurotoxicol. Teratol. 13:347352.

12. Dow-Edwards, D. L. 1989. Long term neurochemical and neurobehavioral consequences of cocaine use during pregnancy. Ann. NY Acad. Sci. 562:280-289.

13. Dow-Edwards, D. L., L. A. Freed, and T. A. Fico. 1990. Structural and functional effects of prenatal cocaine exposure in adult rat brain. Dev. Brain Res. 57:263-268.

14. Spear, L. P., C. L. Kirstein, and N. A. Frambes. 1989. Cocaine effects on the developing CNS: behavioral, psychopharmacological, and neurochemical studies. Ann. NY Acad. Sci. 562:290-307.

15. Akbari, H. M. H. K. Kramer, P. M. Whitaker-Azmitia, L. P. Spear, and E. C. Azmitia. 1992. Prenatal cocaine exposure disrupts the development of the serotonergic system. Brain Res. 572:57-63.

16. Mahalik, M. P., R. F. Gautieri, and D. E. Mann, Jr. 1984. Mechanism of cocaine induced teratogenesis. Res. Commun. Subst. Abuse. 5:279-302.

17. Webster, W. S., and P. D. C. Brown-Woodman. 1990. Cocaine as a cause of congenital malformations of vascular origin: experimental evidence in the rat. Teratology. 41:689-697.

18. Green, L. A., and A. S. Tischler. 1976. Establishment of a noradrenergic clonal line of rat adrenal pheochromocytoma cells which respond to nerve growth factor. Proc. Natl. Acad. Sci. USA. 73:2424-2428.

19. Warren, S., and R. N. Chute. 1972. Pheochromocytoma. Cancer (Phila.). 29:327-331.

20. Greene, L. A., M. M. Sobeih, and K. K. Teng. 1990. Methodologies for the culture and experimental use of the PC-12 rat pheochromocytoma cell line. In Culturing Nerve Cells. G. Banker and K. Goslin, editors. MIT Press, Cambridge, MA. pp. 207-226.

21. Fujita, K., P. Lazarovici, and G. Guroff. 1989. Regulation of the differentiation of PC-12 pheochromocytoma cells. Environ. Health Perspect. 80:127142

22. Schubert, D., S. Heinemann, and Y. Kidokoro. 1977. Cholinergic metabolism and synapse formation by a rat nerve cell line. Proc. Natl. Acad. Sci. USA. 74:2579-2583.

23. Recio-Pinto, E., F. F. Lang, and D. N. Ishii. 1984. Insulin and IGF-2 permit NGF binding and the neurite formation response in cultured human neuroblastoma cells. Proc. Natl. Acad. Sci. USA. 81:2562-2566.

24. Farrar, H. C., and G. L. Kearns. 1989. Cocaine: clinical pharmacology and toxicology. J. Pediatr. 115:665-675.

25. Baslet, R. C. 1982. Cocaine. In Disposition of Toxic Drugs and Chemicals in Man. 2nd ed. Biomedical Publication, Davis, CA. pp. 193-198.

26. Stead, A. H., and A. C. Moffat. 1983. A collection of therapeutic, toxic and fatal blood drug concentrations in man. Human Toxicol. 3:437-464.

27. Martz, R., B. Donnelly, L. Lasswell, G. W. Hime, and W. L. Hearn. 1991 The use of hair analysis to document a cocaine overdose following a sustained survival period before death. J. Anal. Toxicol. 15:279-291.

28. Hime, G., W. L. Hearn, S. Rose, and J. Colfino. 1991. Analysis of cocaine and cocaethylene in blood and tissues by GC-NPD and GC-ion trap mass spectroscopy. J. Anal. Toxicol. 15:241-245.

29. Clark, G., I. B. Rosenzweig, V. Raisys, C. M. Callahan, T. M. Grant, and A. P. Streissguth. 1992. The analysis of cocaine and benzoylecgognine in meconium. J. Anal. Toxicol. 16:261-263.

30. Evans, M., and T. Moriarity. 1980. Analysis of cocaine and cocaine metabolites by high pressure liquid chromatography. J. Anal. Toxicol. 4:19-22.

31. Massoud, A., and D. Krupski. 1980. HPLC analysis of cocaine in human plasma. J. Anal. Toxicol. 4:305-310.

32. Devane, C. L., J. W. Simpkins, R. L. Miller, and S. B. Braun. 1989. Tissue distribution of cocaine in the pregnant rat. Life Sci. 45:1271-1276.

33. Wiggins, R. C., C. Rolsten, B. Ruiz, and C. M. Davis. 1989. Pharmacokinetics of cocaine: basic studies of route, dosage, pregnancy and lactation. Neurotoxicology. 10:367-382.

34. Doberczak, T. M., S. Shanzer, R. T. Senie, and S. R. Kandall. 1988. Neonatal neurologic and electroencephalographic effects of intrauterine cocaine exposure. J. Pediatr. 113:354-358.

35. Rivkin, M., and H. E. Gilmore. 1989. Generalized seizures in an infant due to environmental acquired cocaine. Pediatrics. 84:1100-1102.

36. Bauchner, H., B. Zuckerman, M. McClain, D. Frank, L. E. Fried, and H. Kayne. 1988. Risk of sudden infant death syndrome among infants with in utero exposure to cocaine. J. Pediatr. 113:831-834.

37. Dominguez, R., A. A. Vila-Coro, J. M. Slopis, and T. P. Bohan. 1991. Brain and occular abnormalities in infants with in utero exposure to cocaine and other street drugs. Am. J. Dis. Child. 145:688-695.

38. Wiggins, R. C., and B. Ruiz. 1990. Development under the influence of cocaine: comparison of the effect of maternal cocaine and associated undernutrition on brain myelin development in the offspring. Metab. Brain Dis. 5:101-109. 
39. Gressens, P., B. E. Kosofsky, and P. Evrad. 1992. Cocaine-induced disturbances of corticogenesis in the developing brain. Neurosci. Lett. 140:113-116.

40. Dow-Edwards, D. L., L. A. Freed, and T. H. Milhorat. 1988. Stimulation of brain metabolism by perinatal cocaine exposure. Dev. Brain Res. 42:137-141.

41. Minabe, Y., C. R. Ashby, C. Heyser, L. Spear, and R. Y. Wang. 1992. The effect of prenatal cocaine exposure on spontaneously active midbrain dopamine neurons in adult male offspring: an electrophysiological study. Brain Res. 586:152-156.

42. Seidler, J., and T. A. Slotkin. 1992. Fetal cocaine exposure causes persistent noradrenergic hyperactivity in rat brain regions: effects on neurotransmitter turnover and receptors. J. Pharmacol. Exp. Ther. 154:493-498.

43. Henderson, M. G., M. M. McConnaughey, and B. A. McMillen. 1991. Long term consequences of prenatal exposure to cocaine or related drugs: effects on rat brain monoaminergic receptors. Brain Res. Bull. 26:941-945.

44. Clow, D. W., R. P. Hammer, C. L. Kirstein, and L. P. Spear. 1991. Gestational cocaine exposure increases opiate receptor binding in weanling offspring. Dev. Brain Res. 59:179-185.

45. Raum, W. J., R. F. McGivern, M. A. Peterson, J. H. Shryne, and R. A. Gorsky. 1990. Prenatal inhibition of hypothalamic sex steroid uptake by cocaine: effects on neurobehavioral sexual differentiation in the male rats. Dev. Brain Res. $53: 230-236$.
46. Spear, L. P., C. L. Kirstein, N. A. Frambes, and C. A. Moody, 1990 Neurobehavioral teratogenicity of gestational cocaine exposure. Nat. Inst. Drug Abuse Res. Mon. 95:232-238.

47. Hutchings, D. E., T. A. Fico, and D. L. Dow-Edwards. 1989. Prenatal cocaine: maternal toxicity, fetal effects and locomotor activity of rat offspring. Neurotoxicol. Teratol. 11:65-69.

48. Spear, L. P., C. L. Kirstein, J. Bell, V. Yoottanasumpun, R. Greenbaum, J. O'Shea, H. Hoffman, and N. E. Spear. 1989. Effects of prenatal cocaine exposure on behavior during the early postnatal period. Neurotoxicol. Teratol. 1:5763.

49. Anderson-Brown, T., T. A. Slotkin, and F. J. Seidler. 1990. Cocaine acutely inhibits DNA synthesis in developing rat brain regions: evidence for direct actions. Brain Res. 537:197-202.

50. El-Bizri, H., I. Guest, and D. R. Varma. 1991. Effects of cocaine on rat embryo development in vivo and in cultures. Pediatr. Res. 29:187-190.

51. Inhaba, T., D. J. Stewart, and W. Kalow. 1978. Metabolism of cocaine in man. Clin. Pharmacol. Ther. 23:547-552.

52. Stewart, D. J., T. Inhaba, M. Lucassen, and W. Kalow. 1979. Cocaine metabolism cocaine and norcocaine hydrolysis by liver and serum esterases. Clin. Pharmacol. Ther. 25:464-452. 